\title{
HUBUNGAN ANTARA PENGETAHUAN IBU TENTANG KESEHATAN REPRODUKSI DENGAN SIKAP TERHADAP PENDIDIKAN SEKS BAGI REMAJA DI RAWA PASUNG, BEKASI BARAT
}

\author{
Correlation between Mother's Knowledge on Health Reproduction \\ and Attitude towards Sex Education For Adolescent In Rawa Pasung, \\ West Bekasi \\ Refirman, Sri Rahayu, Anggi Anggraini \\ Corresponding author; email: anggianggraini180@yahoo.co.id
}

\begin{abstract}
ABSTRAK
Adolescent is a transitional period from childhood to the adulthood in which the adolescents have a high curiosity to know and to understand the changings occurred to themselves. The adolescents need intense information on sexuality, additionally mother's have on essential role to educate them. This research aimed to determine the relationship between mother's knowledge on health reproductive and attitude in sexual education for adolescents. This research was conducted on Mey-June 2016. The method used was descriptive method with correlational study. The population was mothers who have adolescents aged 10-19 years. The sample was conducted by simple random sampling about 124 mothers. The prerequisite test showed that the data was normal and homogenous. The first hypothesis test was using linear regression and simple correlation. Regression model obtained was $\hat{Y}=69,821+0,150 \mathrm{X}$ it was significant and linear relationship. The coefficient of correlation obtained was 0.174 , which meaning that there was a positive-significant correlation between mother's knowledge on health reproductive and attitude towards sex education. The coefficient of determination obtained was 0.03 which meaning that mother's knowledge on health reproduction contributed about $3 \%$ to the attitude towards sex education.
\end{abstract}

Keywords : Knowledge, health reproduction, attitude, sex education

\section{PENDAHULUAN}

Perkembangan ilmu dan teknologi yang semakin canggih mempermudah masyarakat khususnya remaja memperoleh informasi dari berbagai media cetak maupun elektronik. Masuknya informasi ke kalangan remaja dapat membentuk perilaku positif maupun negatif. Remaja dengan mudah memperoleh ilmu pengetahuan yang bermanfaat, namun sangat rentan terpapar informasi salah satunya berupa tayangan pornografi melalui internet. Keterpaparan pornografi membawa pengaruh signifikan pada perkembangan seksual remaja (Ybarra \& Mitchell, 2005).

Berdasarkan sensus penduduk Indonesia tahun 2010, kelompok remaja dengan rentangan usia 10-19 tahun memiliki proporsi 18,3\% dari total penduduk yang berjumlah 233 juta jiwa. Proporsi tersebut merupakan aset penting bagi negara. Namun, tingginya jumlah remaja diikuti dengan berbagai permasalahan salah satunya adalah masalah kesehatan reproduksi. Permasalahan kesehatan reproduksi yang berisiko mengancam remaja antara lain seks bebas, kehamilan yang tidak diinginkan, aborsi dan 
penyakit menular seksual. Penelitian Aritonang tahun 2015, pada pelajar SMK di Tambun kabupaten Bekasi sebesar 68\% remaja usia 15-17 tahun telah melakukan hubungan seksual sebelum menikah. Salah satu faktor terjadinya perilaku seks pada remaja adalah kurangnya pengawasan dan pengetahuan orang tua serta rendahnya pengawasan lingkungan (Santrock, 2003; Lestary \& Sugiharti, 2011). Pendidikan seks merupakan tanggung jawab orang tua karena orang tua atau lingkungan keluarga menjadi landasan dasar dalam membentuk kepribadian anak (Gunarsa, 2004; Nyarko et al, 2014).

Hingga kini, masalah pendidikan seks masih menimbulkan kontroversi. Mayoritas orang tua masih enggan terbuka untuk berbicara tentang seks kepada anaknya (Wilson, 2010). Hal ini dikarenakan kurangnya pengetahuan orang tua tentang seks, masih menganggap seks merupakan hal yang tabu dan perasaan malu yang membuat para orang tua enggan memberikan pendidikan seks (Mahajan \& Sharma, 2005; Meilani, 2014).

\section{METODELOGI PENELITIAN}

Populasi target dalam penelitian ini adalah seluruh ibu yang mempunyai anak remaja di kota Bekasi. Populasi terjangkaunya adalah ibu yang mempunyai anak remaja usia 10-19 tahun yang tinggal di Kelurahan Kali Baru, Bekasi Barat, yang dipilih dengan menggunakan cluster random sampling.

Berdasarkan data dari rekapitulasi hasil pendataan keluarga tahun 2016, terdapat 4284 jumlah ibu yang tinggal di Kelurahan Kali Baru. Dari Kelurahan Kali Baru yang ada dipilih RW 04 dari 8 RW secara purposive sampling sebagai sampel penelitian. Jumlah ibu yang berada di RW 04 sebanyak 573 orang.

Kriteria sampel yang diambil adalah ibu yang memiliki anak remaja usia 10-19 tahun yang telah diasuhnya dari kecil sampai penelitian ini berlangsung. Sampel tinggal bersama dalam satu rumah yang terdiri dari ayah, ibu dan anak. Berdasarkan kriteria tersebut didapatkan dua RT yang dipilih sebagai sampel penelitian yaitu RT 01 dan RT 02. Dalam penelitian ini jumlah responden sebanyak 180 ibu. Sampel ditentukan dengan teknik simple random sampling menggunakan rumus Taro Yamane sehingga diperoleh 124 orang

\section{HASIL DAN PEMBAHASAN}

1. Karakteristik Responden

a. Umur

Sebagian responden berumur 30-49 tahun yaitu sebanyak 98 responden (79\%). Minoritas umur responden berada pada rentang umur $>49$ tahun $(6 \%)$.

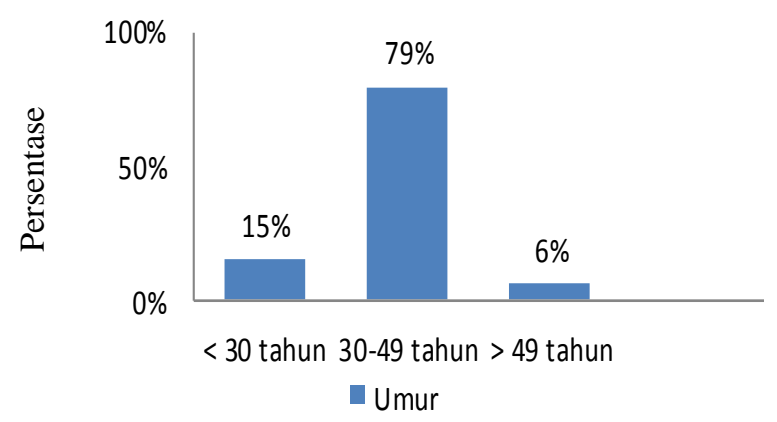

Gambar 1. Distribusi Umur Responden 
b. Pendidikan

c. Pendidikan responden terbanyak adalah SD berjumlah 45 responden $(36 \%)$ dan yang paling sedikit adalah responden dengan tingkat pendidikan D3 sebanyak 1 responden $(1 \%)$.

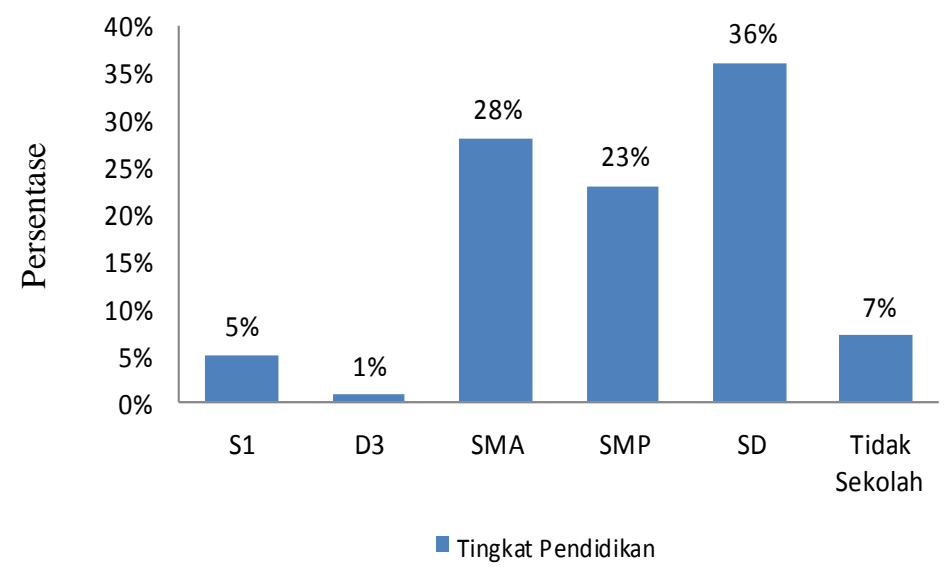

Gambar 2. Tingkat Pendidikan Responden

d. Pekerjaan

Mayoritas pekerjaan responden adalah Ibu Rumah Tangga sebanyak 68 responden (55\%) dan minoritas pekerjaan responden adalah PNS dan Pegawai Swasta sebanyak 2 responden atau masing masing sebesar $2 \%$.

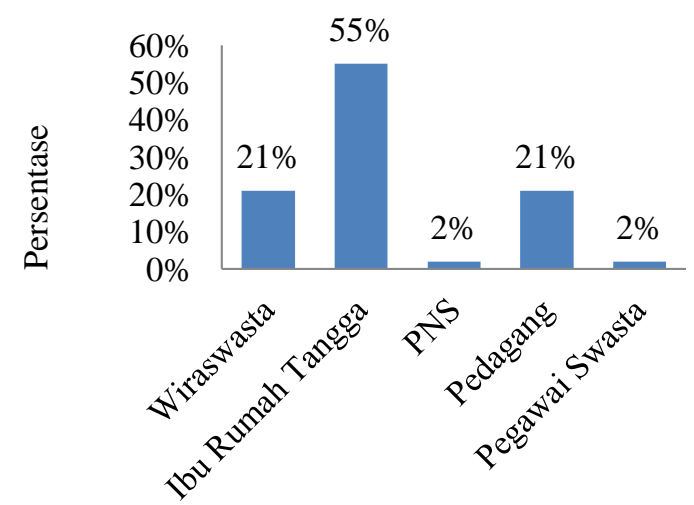

Gambar 3. Tingkat Pekerjaan Responden

e. Status Ekonomi

penghasilan keluarga dengan jumlah responden yang memiliki penghasilan perbulan < Rp 1000.000 sebanyak 50\%. Sedangkan jumlah responden yang memiliki penghasilan perbulan $>$ Rp 3.000 .000 sebanyak $6 \%$.

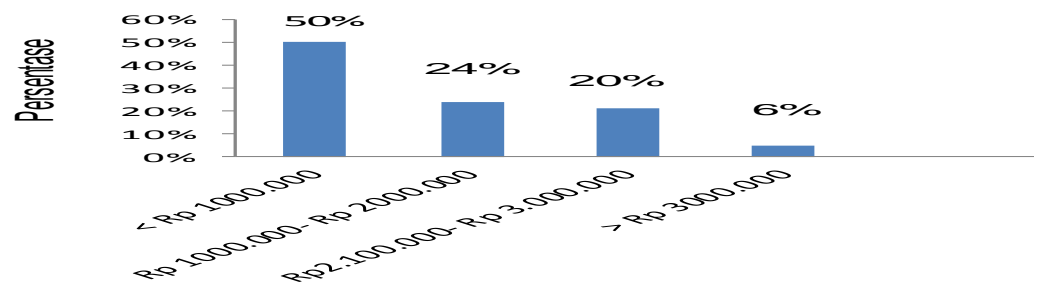

Gambar 4. Tingkat Pendapatan Responden Perbulan 
2. Pengetahuan Ibu Tentang Kesehatan Reproduksi

Sebagian besar responden memiliki kriteria pengetahuan baik tentang kesehatan reproduksi yaitu sebanyak $58 \%$.

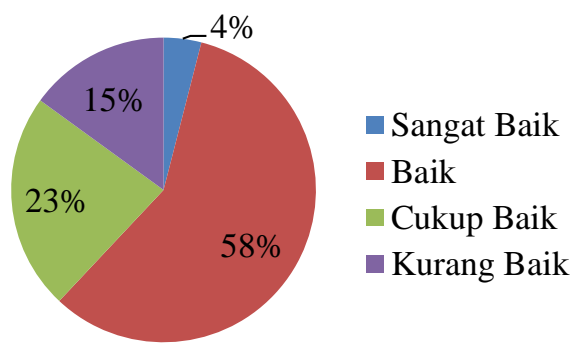

Gambar 5. Kriteria Pengetahuan Responden tentang Kesehatan Reproduksi

3. Sikap terhadap Pendidikan Seks

Berdasarkan hasil penelitian yang diperoleh didapatkan 2 kategori sikap yaitu Sebanyak 61 responden (49\%) sudah memiliki sikap pendidikan seks yang sangat baik dan sebanyak 63 responden $(51 \%)$ memiliki sikap baik terhadap pendidikan seks.

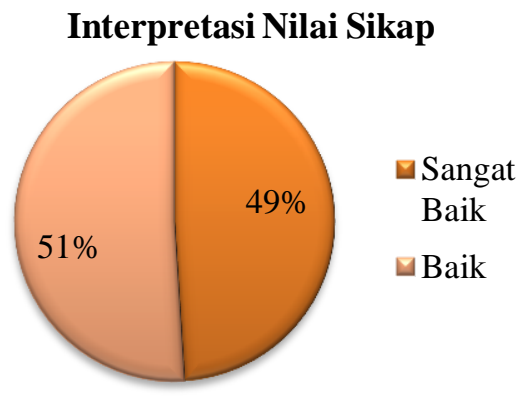

Gambar 6. Kriteria Nilai Sikap Responden terhadap Pendidikan Seks

Berdasarkan hasil pengujian keberartian signifikansi diperoleh nilai signifikansi 0,036 maka terima $\mathrm{H}_{0}$, artinya model regresi $\hat{\mathrm{Y}}=69,821+0,150 \mathrm{X}$ merupakan model regresi yang signifikan. Untuk hasil pengujian linieritas diperoleh nilai signifikansi 0,036. Hal ini berarti model regresi tersebut memiliki bentuk hubungan yang linier. Berikut ini grafik persamaan arah regresi dapat dilihat pada Gambar 7 di halaman berikutnya.

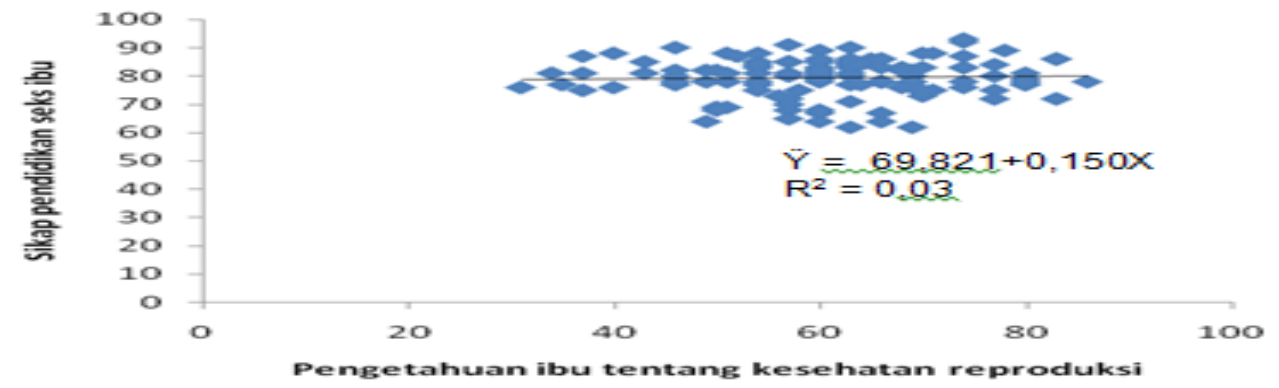

Gambar 7. Grafik regresi linear hubungan antara pengetahuan ibu tentang kesehatan reproduksi dengan sikap ibu terhadap pendidikan seks bagi remaja 
Pengujian prasyarat menunjukkan bahwa data normal dan homogen. Oleh karena itu, pengujian korelasi menggunakan rumus Pearson Product Moment dengan program SPSS 16.0. Berdasarkan hasil perhitungan, didapatkan koefisien korelasi $\left(\mathrm{r}_{\mathrm{xy}}\right)$ adalah 0,174. Besarnya koefisien determinasi dari hasil perhitungan adalah 0,03 atau 3\%. Artinya kontribusi pengetahuan ibu tentang kesehatan reproduksi sebesar 3\% sedangkan $97 \%$ dipengaruhi faktor lain.

Hasil penelitian ini menunjukkan bahwa tiap responden memiliki pengetahuan yang berbeda-beda. Mayoritas reponden memiliki kriteria pengetahuan yang baik sebanyak 58\% dan minoritas responden memiliki kriteria pengetahuan sangat baik sebanyak 4\%. Tingginya tingkat pengetahuan baik yang dimiliki ibu merupakan salah satu aspek penting pada sebuah keluarga dalam memberikan pendidikan seks bagi remaja. Perbedaan tingkat pengetahuan ibu dipengaruhi oleh beberapa faktor antara lain pendidikan, umur, paparan sumber informasi, sosial ekonomi, dan pengalaman (Notoatmodjo, 2010).

Tingkat pendidikan memiliki kontribusi terhadap pengetahuan ibu. Berdasarkan pemikiran bahwa pendidikan salah satu upaya untuk mendapatkan pengetahuan secara formal. Pendidikan formal mengajarkan berbagai hal pengetahuan. Menurut Wulandari, Maria Komariah dan Ermiaty (2008) mengatakan bahwa orang yang berpendidikan tinggi akan memiliki pengetahuan yang lebih baik dibandingkan dengan seseorang yang tingkat pendidikannya lebih rendah. Hal ini terlihat dari hasil penelitian, bahwa ibu yang tingkat pendidikannya tinggi memiliki pengetahuan yang baik. Pada hasil penelitian ini juga diketahui bahwa $15 \%$ responden memiliki kriteria kurang baik, hal ini dikarenakan tingkat pendidikan yang rendah dimana mayoritas ibu tingkat pendidikannya adalah SD sebanyak 36\% dan Tidak sekolah sebanyak $7 \%$. Selain itu, pengalaman merupakan salah satu faktor yang memiliki kontribusi terhadap pengetahuan ibu. Berdasarkan hasil wawancara, diketahui bahwa mayoritas responden sewaktu masih anak-anak mendapatkan pendidikan seks dari ibu mereka. Hal ini sejalan dengan teori yang menyatakan bahwa manusia adalah individu sebagai orang yang menerima pengalaman dan orang yang melakukan penghayatan biasanya tidak melepaskan pengalaman yang dialaminya (Nursalam \& Pariani, 2001). Selanjutnya, menurut Notoatmodjo (2010), pengetahuan yang dimiliki seseorang diperoleh dari pengalaman diri sendiri, orang lain dan dari lingkungan sekitar.

Umur juga memiliki kontribusi terhadap pengetahuan yang dimiliki seseorang karena adanya perbedaan pola pikir saat usianya semakin bertambah (Notoatmodjo, 2007). Semakin tinggi daya tangkap dan semakin baik pola pikir maka semakin tinggi pula pengetahuan yang dimiliki. Pada penelitian ini, mayoritas umur responden yang memiliki anak remaja berada dalam rentang umur 30-49 tahun sehingga mereka memiliki banyak pengetahuan dan pengalaman dibandingkan seseorang yang berumur muda.

Pengetahuan ibu yang baik didukung pula oleh salah satu faktor yaitu sumber informasi. Hal ini ditunjukkan bahwa sebagian besar responden memperoleh informasi dari kegiatan pengajian dan penyuluhan terkait kesehatan reproduksi. Hal ini sesuai dengan teori Mubarak dkk (2007), bahwasanya penyuluhan adalah salah satu metode yang dapat digunakan untuk meningkatkan pengetahuan sehingga akan membentuk sikap seseorang.

Selain itu, Faktor sosial ekonomi juga mendukung peningkatan pengetahuan ibu. Pada hasil penelitian, terlihat bahwa kriteria pengetahuan ibu menunjukkan bahwa terdapat $4 \%$ responden pengetahuan sangat baik, 58\% pengetahuan baik, $23 \%$ 
responden pengetahuan cukup baik. Hal ini dikarenakan mayoritas pekerjaan ibu sebagai ibu rumah tangga. Menurut Purnama Yenny dkk (2008) dari hasil penelitiannya diketahui bahwa ibu rumah tangga berpotensi mendapat peluang mencari pengetahuan lebih banyak baik secara waktu terluang, ketidaksibukan dan kemampuan intelektual. Sedangkan $15 \%$ responden memiliki kriteria pengetahuan kurang baik. Hal ini dikarenakan masing-masing responden ada yang bekerja sebagai pedagang dan wiraswasta. Selain itu, dipengaruhi juga oleh penghasilan keluarga dimana rata-rata dibawah satu juta sehingga mereka sibuk mencari nafkah.

Faktor-faktor diatas menunjukkan bahwa pengetahuan yang tinggi menghasilkan sikap terhadap pendidikan seks yang baik. Berdasarkan hal tersebut, Notoatmodjo (2003) memaparkan bahwa tindakan yang didasari pengetahuan akan lebih baik dibandingkan tanpa didasari pengetahuan.

Hasil perhitungan menunjukkan terdapat hubungan positif yang signifikan antara pengetahuan ibu tentang kesehatan reproduksi dengan sikap ibu terhadap pendidikan seks bagi remaja. Hal ini berarti semakin tinggi pengetahuan ibu tentang kesehatan reproduksi, maka sikap mereka terhadap pendidikan seks menjadi semakin baik. Seperti yang diungkapkan Ancok (2013) bahwa antara pengetahuan dan perilaku sangat berkaitan erat, pengetahuan akan membentuk sikap, kemudian dari sikap itu akan membentuk perilaku.

Pada perhitungan koefisien korelasi diperoleh hasil nilai korelasi sebesar 0,174. Hasil tersebut masuk kedalam interval koefisien korelasi 0,00-0,199 sehingga berada dalam kategori sangat rendah (Hasan 2006). Hal ini menunjukkan bahwa pengetahuan ibu tentang kesehatan reproduksi memiliki hubungan yang sangat rendah dengan sikap ibu terhadap pendidikan seks. Hasil penelitian ini sesuai dengan penelitian Arcury (1990), bahwa pengetahuan dan sikap memiliki hubungan walaupun hubungannya tidak terlalu kuat sehingga implikasi atau penerapan pengetahuan terhadap sikap tidak berpengaruh besar. Menurut Sukidjo (2007), Pengetahuan kesehatan reproduksi dapat menyebabkan terjadinya perubahan sikap manusia secara langsung mempengaruhi pola perilaku.

Pengetahuan didalam penelitian ini merupakan suatu faktor yang memberi kontribusi terhadap sikap kesehatan reproduksi. Berdasarkan perhitungan nilai determinasi diperoleh sebesar 3\% yang menunjukkan kontribusi dari pengetahuan ibu tentang kesehatan reproduksi terhadap pendidikan seks bagi remaja hanya sebesar 3\% dan sisanya sebesar 97\% ditentukan oleh faktor lain. Menurut Shoben (1949), mengungkapkan bahwa demografi, status sosial ekonomi, tingkat pendidikan, pengaruh ras dan etnis, usia serta jenis kelamin anak berkontribusi terhadap sikap ibu terhadap pendidikan seks. Struktur keluarga juga berkontribusi terhadap sikap terhadap pendidikan seks ditemukan dalam studi penelitian Touliatos dan Lindholm (1980). Penelitian lain juga menemukan beberapa faktor yang berkontribusi terhadap pendidikan seks antara lain sosial ekonomi, lingkungan sosial dan struktur keluarga (Vashistha \& Rajhree, 2012).

\section{KESIMPULAN DAN SARAN}

Berdasarkan hasil penelitian maka dapat disimpulkan bahwa terdapat hubungan positif yang signifikan antara pengetahuan ibu tentang kesehatan reproduksi dengan sikap ibu terhadap pendidikan seks remaja. Faktor-faktor yang mempengaruhi pengetahuan antara lain, pendidikan, umur, paparan media massa, sosial ekonomi, dan pengalaman. 
Berdasarkan hasil penelitian yang telah dilakukan mengenai hubungan pengetahuan ibu tentang kesehatan reproduksi dengan sikap terhadap pendidikan seks bagi remaja di Rawa Pasung, Bekasi Barat, maka saran yang diberikan peneliti sebagai berikut:

a. Bagi Dinas Kesehatan Kota Bekasi dan Dinas Kesehatan Setempat serta pihak-pihak lain yang terkait.

Saran yang dapat diajukan adalah perlu melakukan promosi kesehatan yang bertujuan untuk menanamkan sikap positif pada ibu terhadap pendidikan seks anak. Hal ini dapat dilakukan dengan mengadakan penyuluhan mengenai masalah kesehatan khususnya mengenai pendidikan seks.

b. Bagi Orang Tua

Kepada orang tua diharapkan dapat meningkatkan pengetahuan pendidikan seks bagi remaja melalui berbagai sumber bacaan yang terkait masalah tersebut. Prinsipnya dalam penyampaian pendidikan seks pada anak, ibu harus terbuka, jujur dan bersikap positif serta menggunakan bahasa yang sesuai dengan tingkatan umur anak.

c. Bagi peneliti selanjutnya

Saran yang dapat diajukan adalah perlu dilakukan penelitian terhadap faktor lain yang mempengaruhi sikap terhadap pendidikan seks selain pengetahuan ibu tentang kesehatan reproduksi. Selain itu, perlu dilakukan penelitian lebih mendalam mengenai peran orang tua dalam membangun komunikasi dalam memberikan pendidikan seks pada remaja

\section{DAFTAR PUSTAKA}

Ancok, K. (2013). Aplikasi Ilmu Perilaku Dalam Pengembangan Sumberdaya Manusia, Edisi Revisi. Yogyakarta: UII Press.

Arcury Thomas (1990). Environmental Attitude and Environmental Knowledge. Human Organization: Winter, 49 (4): 300-304.

Aritonang, Tetty R. (2015). Hubungan Pengetahuan dan Sikap Tentang Kesehatan Reproduksi dengan Perilaku Seks Pranikah Pada Remaja Usia (15-17 Tahun) di SMK Yadika 13 Tambun, Bekasi. Jurnal Ilmiah WIDYA, 3 (2): 61-67

Gunarsa. (2004). Psikologi Remaja. Jakarta: Gunung Mulia.

Hurlock, E. B. 1973. Adolescent Development. USA: Mc. Groaw Hill. Inc.

Hasan, I. (2006). Analisis Data Penelitian dengan Statistik. Jakarta: PT. Bumi Aksara.

Mahajan, P., \& Sharma, N. (2005). Parents attitude towards imparting sex education to their adolescent girls. Anthropologist, 7(3), 197-199.

Notoadmojo, Soekidjo. (2003). Promosi Kesehatan Teori dan Aplikasi. Jakarta: Rineka cipta

Shoben, E. J.Jr. (1949). The Assessment of Parent Attitudes in Relation to Child Adjustment. Genetic Psychology Monograph, 34, 101-148.

Touliatos, J.,\& Lindholm, B. W. (1980). Teacher's Perception of Behaviour Problems in Children From Infact, Single-Parent, and Stepparent Families. Pschology in The Schools, 17(2), 264-269.

Vashistha \& Rajshree. (2012). A Study of Attitude towards Sex Education a Perceived by Parents \& Teacher. Samwaad, 1 (2).

Wilson, Ellen at al. (2010). Parents' Perspective on Talking to Preteenage Children About Sex. Perspective on Sexual and Reproductive Health, 42 (1): 56-63. 
Ybarra, M., \& Mitchell, K. J. (2005). Exposure to Internet Pornography a Mong Children and Adolescents: A National Survey. Chyber Psychologi \& Behaviour, 8(5),473 